\title{
浸炭材のピッチング疲労強度に及ぼすすべり条件の影響 \\ 牧野泰三*堀本雅 之松本 斉** \\ Effect of Slip Condition on the Contact Fatigue Strength for Pitting of the Carburized Steel
}

by

\author{
Taizo Makino ${ }^{*}$, Masayuki Horimoto ${ }^{* *}$ and Hitoshi Matsumoto ${ }^{* *}$
}

The objective of the present paper is to clarify the effect of slip condition, ie. slip ratio, outer surface velocity, and lubrication oil temperature on the contact fatigue strength for pitting (pitting strength) of the carburized steel. Rolling contact fatigue (RCF) tests were conducted on $26 \mathrm{~mm}$ diameter specimens made of carburized steel under oil lubrication. Then, slip ratio, outer surface velocity, and lubrication oil temperature as the slip condition were changed on the RCF tests. As a result, pitting strength decreased with the increase of slip ratio, the decrease of outer surface velocity, and the decrease of lubrication oil temperature. Furthermore, relationships between the above-mentioned three parameters, friction coefficient, and contact surface temperature were evaluated. Then slip ratio, outer surface velocity, and lubrication oil temperature influenced to friction coefficient and contact surface temperature. The friction coefficient slightly decreased when contact surface temperature increased. Lastly, it was found that the friction coefficient was main parameter which directly determines the pitting strength.

Key words : Rolling contact fatigue (RCF), Slip condition, Pitting, Carburized steel, Friction coefficient, Lubrication oil temperature, Contact surface temperature

\section{1 緒 言}

㐘車柬面に生じる損傷形態としてピッチングが挙げら れる，ピッチングは，油潤滑下で転がり接触にともなう 繰返し応力の作用により発生し，すべり条件によりその 発生限度が大きく変化することが知られている.1) 3)

実際の菌車では，かみあいにともないすべり率および 面圧が変化するのに対し，ピッチングを再現するために 用いられる 2 円筒転がり接触タイプの試験機では，すべ り率と面圧は，試験を開始してからピッチングが発生し て終了するまで，通常一定である。したがって，実際の 茵車菌面のピッチングに関する疲労限度（以下，ピッチ ング強度と呼ぶ）を定量的に評価するには，種々のすべ り条件下のピッチング強度を把握しておく必要がある. ピッチング強度に及ぼすすべり条件の影響としては，これ まで，すべり率，接触面温度等の特定因子の影響を扱っ た例 ${ }^{4) \sim 6)}$ (多数あるが，すべり率，周速，および潤滑油 温度の影響を総合的に評価した検討は少ない。

そこで，本研究では，浸炭材を対象として，ピッチング 強度に及ぼすすべり率，周速，および潤滑油温度等のす ベり条件の影響を明らかにすることを目的とし，油潤滑に よる種々のすべり条件下で転がり接触疲労試験を行った.

\section{2 供試材, 試験片, および試験方法}

\section{$2 \cdot 1$ 供試材}

供試材はJIS SCM822 を若干改良した成分系の低合金 鋼7)である.Table I に化学成分を示す。この鋼片を鍛
- Table I. Chemical composition.

\begin{tabular}{|c|c|c|c|c|}
\hline $\mathrm{C}$ & $\mathrm{Si}$ & $\mathrm{Mn}$ & $\mathrm{Cr}$ & Mo \\
\hline \hline 0.21 & 0.10 & 0.78 & 1.02 & 0.41 \\
\hline
\end{tabular}

伸し，1523K から空冷の溶体化処理，続いて $1198 \mathrm{~K}$ から 空冷の焼準処理を行った。そして，粗機械加工，Fig. 1 に示すパターンの浸炭焼入れ・焼もどし処理，仕上げ加 工を行い, 試験片を得た。

\section{$2: 2$ 試験片}

Fig. 2 に，試験片形状を示す。試験片は，ピッチング を発生させる小ローラーと，その相手材である大ローラー から構成される。両者はともに同じ供試材から製作され ているが, 小ローラーの接触面 (中央 $\phi 26 \mathrm{~mm}$ の外周部) は浸炭後黒皮ままであるのに対し，大ローラーの接触面 （外周部）は浸炭後ペーパー研磨して黒皮を除去してい る.Fig. 2 中には，小ローラーと大ローラーの接触状況 も示している。これより，小ローラーと大ローラーが幅

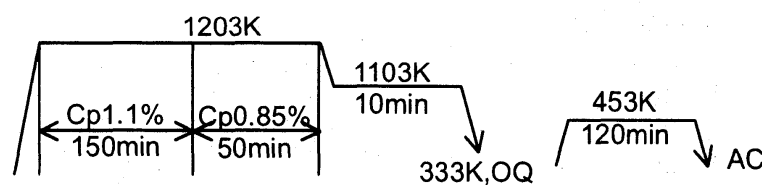

Fig. 1. Pattern of carburized treatment.

\footnotetext{
$\dagger$ 原稿受理 平成 15 年 2 月 10 日 Received Feb. 10, 2003

* 正 会 員 (株住友金属小倉 广802-8686 北九州市小倉北区許斐町, Sumitomo Metals (Kokura), Ltd., Kokurakita-ku, Kitakyushu, 802-8686

** (株)住友金属小倉 T802-8686 北九州市小倉北区許斐町, Sumitomo Metals (Kokura), Ltd., Kokurakita-ku, Kitakyushu, 802-8686
} 


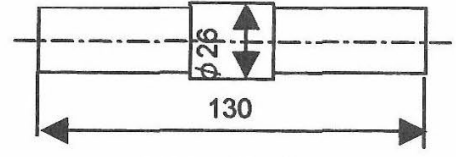

(a)Small roller

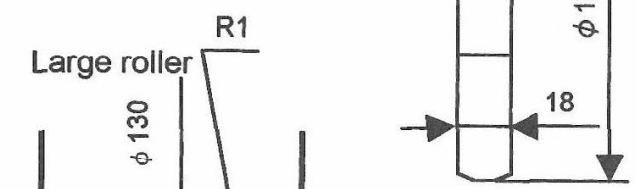

(b)Large roller

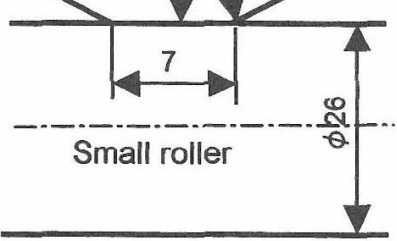

(c)Contact condition between small and large roller

Fig. 2. Configuration of test specimens.

$7 \mathrm{~mm}$ で線接触していることがわかる。なお，小ローラー， 大ローラー接触面の表面粗さは $\mathrm{R}_{\max }$ で $0.64 \sim 2.61 \mu \mathrm{m}$, $\mathrm{R}_{\mathrm{a}}$ で $0.10 \sim 0.27 \mu \mathrm{m}$ であった。

Fig. 3 に小ローラー接触面下のビッカース硬さ分布を 示す。表面硬さはHV650～700, 有効硬化層深さ（HV 500 以上の範囲）は約 $1 \mathrm{~mm}$ となっている。Fig. 4 に小 ローラー接触面トの X 線残留応力分布を示す。ここで, 残留応力の方向は円周方向である。Fig. 4 より, 表面 に-200〜-350MPa の圧縮残留応力が生じていることが わかる。Fig. 5 に, 試驧片横断面のミクロ組織の光学顕

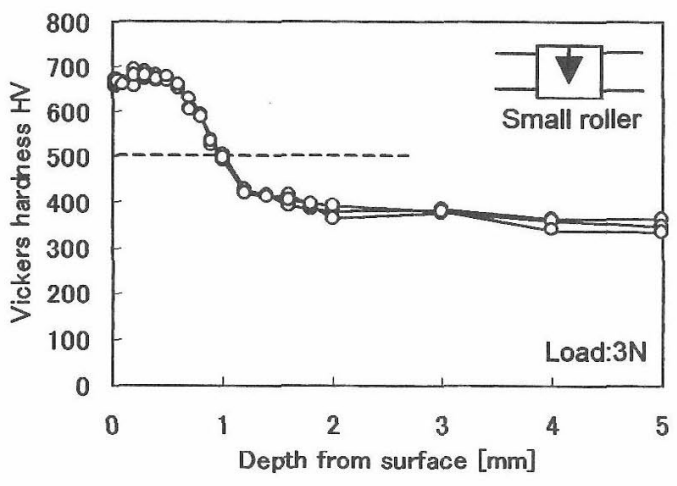

Fig. 3. Vickers hardness distribution.

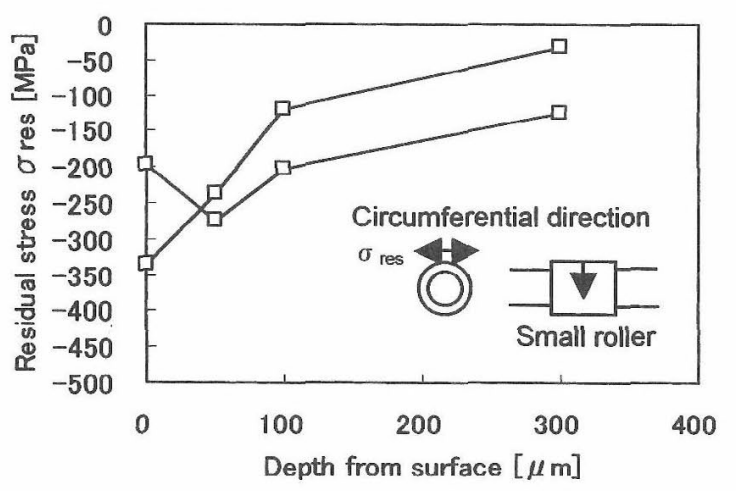

Fig. 4. X-ray residual stress distribution.

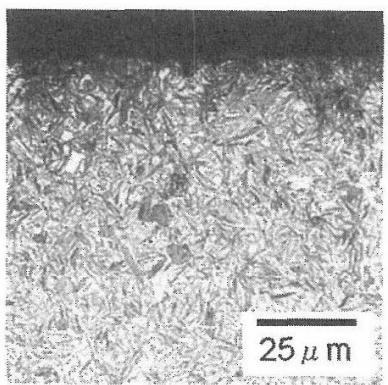

(a)Below surface

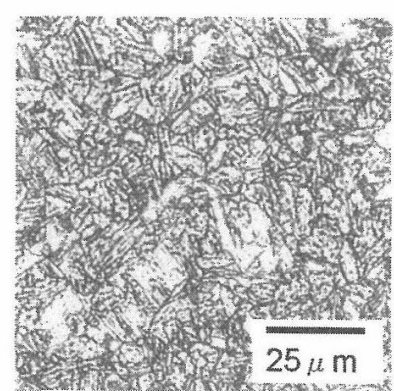

(b) R/2(6.5 mm in depth)
Fig. 5. Micro structure on cross section of small roller.

微鏡写真を示す。表面近傍では高炭素の焼もどしマルテ ンサイト，则部では低炭素の焼もどしマルテンサイト一 ベイナイトの混合組織となっている。また，表面直下に 浸炭まま黒皮の圭面性状に起因した深さ $10 \mu \mathrm{m}$ 程度の不 完全焼大れ組織が生じている。

\section{$2 \cdot 3$ 試験方法}

試験機には，2 円筒転がり接触型疲労試験機（コマッ エンジニアリング製）を用いた。 Fig. 6 に，本試験機の 構造の模式図を示す。図からわかるように，小ローラーと 大ローラーが転がり接触する構造となっている。試験片の 押付け荷重は, 大ローラー側に取付けた負荷レバーに載 荷した重錘重量で設定している。 小ローラー, 大ローラー 間のすべりは，旮れぞれの回転軸に取り付けた菌車の蒌 数比によって調整している。また, 試験中, 小ローラー と大ローラーの接触部に, 設定温度に制御した潤滑油を $21 / \mathrm{min}$ 噴射している。潤滑油の種類は, 自動車オートマ チックトランスミッション用オイルである。

試験では, 小ローラーの累積回転数（以後, 繰返し数 と呼ぶ)で, $1 \times 10^{7}$ を打切り繰返し数としている。試験 途中で，ピッチングが発生した場合，負荷レバー上に取 り付けた振動センサーで感知して, 試験を自動停止させ ている，なお，試騟前に繰返し数で約 $3 \times 10^{4}$ 回，無負 荷によるならし運転を行っている。

試験条件としては，すべり率で40～160\%，潤滑油温 度 (以下, 単に油温と呼ぶ) で $313,353 \mathrm{~K} の 2$ 段階，小 ローラーの周速 $\left(\mathrm{V}_{\mathrm{s}}\right)$ で $0.41,1.36 \mathrm{~m} / \mathrm{s} の 2$ 段階をパう メータとして採用している。ここで, すべり率 $\left(\mathrm{S}_{\mathrm{r}}\right)$ の定 義を次式に示す。

$$
\mathrm{S}_{\mathrm{r}}=\left(\mathrm{V}_{\mathrm{L}}-\mathrm{V}_{\mathrm{S}}\right) / \mathrm{V}_{\mathrm{S}}
$$

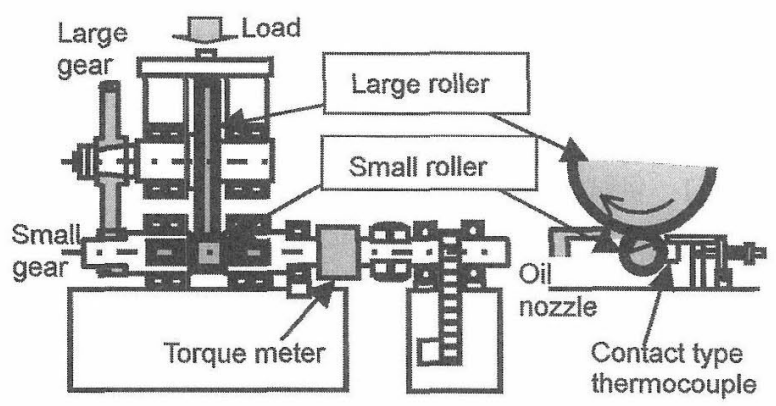

Fig. 6. Schematic illustration for testing apparatus. 
Table II. Test conditions.

\begin{tabular}{|c|c|c|c|c|}
\hline \begin{tabular}{|} 
Outer surface velocity \\
of small roller $\mathrm{V}_{\mathrm{S}}[\mathrm{m} / \mathrm{s}]$
\end{tabular} & 1.36 & 1.36 & 0.41 \\
\hline \multicolumn{2}{|c|}{ Oil temperature [K] } & 353 & 313 & 313 \\
\hline \multirow{3}{*}{$\begin{array}{c}\text { Slip } \\
\text { ratio } \\
\mathrm{S}_{\mathrm{r}}[\%]\end{array}$} & 40 & $\mathrm{X}$ & $\mathrm{X}$ & - \\
\cline { 2 - 5 } & 80 & $\mathrm{X}$ & $\mathrm{X}$ & $\mathrm{X}$ \\
\cline { 2 - 5 } & 120 & $\mathrm{X}$ & - & - \\
\cline { 2 - 5 } & 160 & $\mathrm{X}$ & $\mathrm{X}$ & - \\
\hline
\end{tabular}

$\mathrm{X}$ : tested, - : not tested

ここで, $\mathrm{V}_{\mathrm{L}}$ ：大ローラー周速， $\mathrm{V}_{\mathrm{s}}$ ：小ローラーの周速 Table IIに，各パラメータについて，試験を行った組合 せを示している。

\section{3 試 験 結 果}

\section{$3 \cdot 1$ 損傷形態と $\mathrm{S}-\mathrm{N}$ 線図}

試験では，ピッチングのほか，學付き，スコーリング 等の損傷が生じた。Fig. 7 に, 試験で生じた損傷の代表 例の外観写真定示す。大部分のピッチングは，図中 (a)

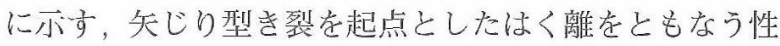
状であった。ただし，ピッチングと分類した中の一部で， 罒中 (b)に示す形状のはく離（ここではスクエア型と呼 ぶ）が観察された。スクエア型では，外観だけでなく， 表面下のき裂の進展形態も矢じり型と異なる。詳細は, 後の $4 \cdot 3$ 節で述べる。一方, 焼付きは, 図中 (c) に示 すように，円周方向にすべりにともなう無数の傷をとも なう性状であった。また，スコーリングは，図中 (d) に 示すように，小ローラー接触面全面の著大な摩耗と多数 のはく離をともなう性状であった。ここで，藷大な摩耗 とは, 深さにして $0.03 〜 0.1 \mathrm{~mm}$ のレベルである。ちな みにピッチングが生じた試験片では，接触面の深さ(摩 耗または変形による) は， $0.01 \mathrm{~mm}$ 以下であった。以下

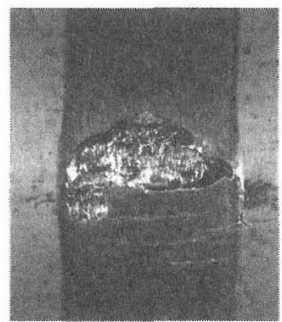

(a)Pitting

(Arrow-head type)

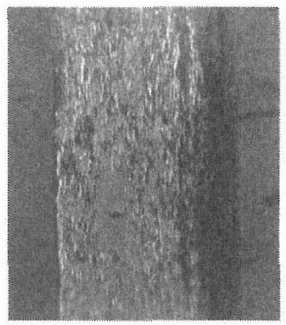

(c)Lubrication failure

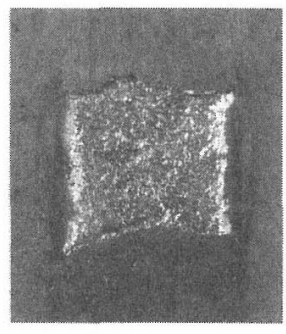

(b) Pitting (Square type)

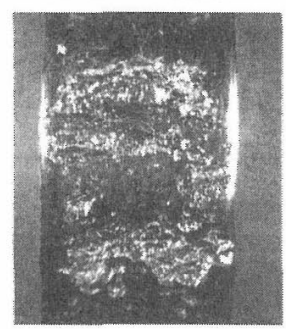

(d) Scoring
Fig. 7. Outer view of typical failure on small roller.
では，スコーリングは焼付きと同様，潤滑不良に起因し た損傷として扱うこととした。

Fig. 8 に，試験で得られた S-N 線図を示す。図の (a) と（b）は油温で区分しており，図中のプロット点はすべ り率拉よび周速で区分している。さらに，スコーリング または焼付きが生じたプロット点には「/」を付記して いる。本図より，ピッチング強度として，ピッチングが 発生しない最大のヘルツ応力と, 焼付き限度として, 焼 付きまたはスコーリングが発生する最小のへルツ応力を 求めた。その結果の一覧を Table III示す。

Fig. 8 とTable IIIより，高すべり率で焼付きが生じや すくなることがわかる。このため，すべり率 $120 \%$ 以上で は，ピッチングより焼付きが先に発生するために，ピッチ ング強度が明らかにならなかった。また，油温 $353 \mathrm{~K} ， す$

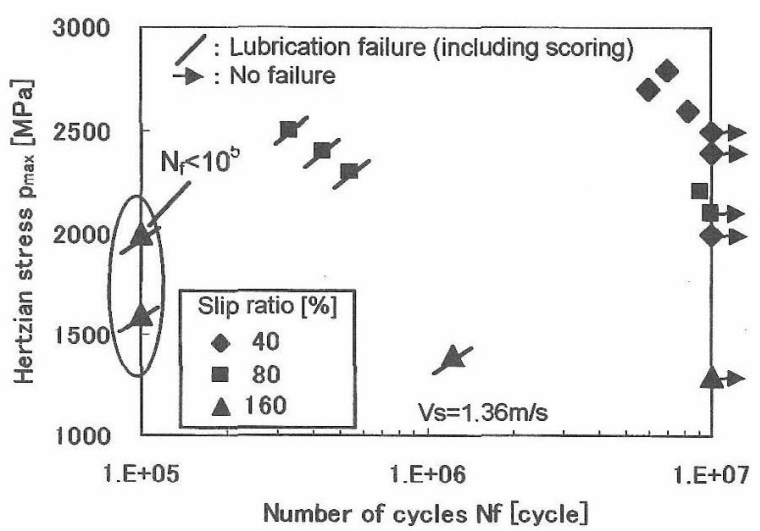

(a)Oil temp. 353K

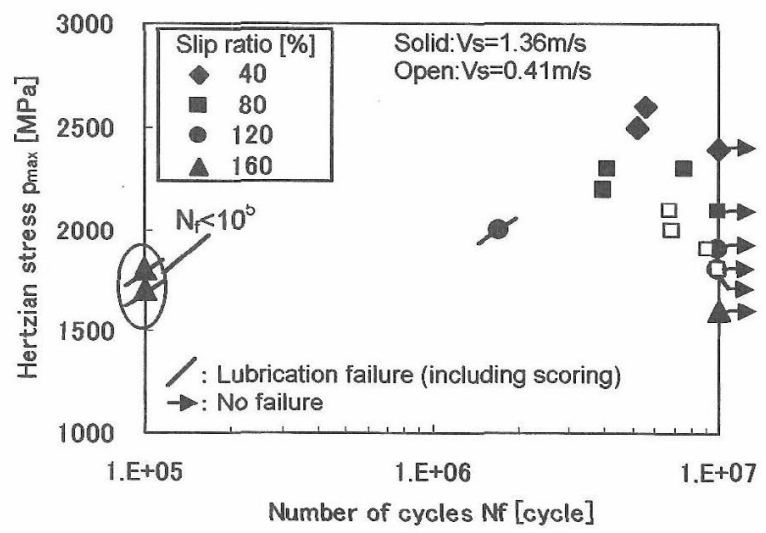

(b) Oil temp. 313K

Fig. 8. S-N diagrams.

Table III. List of fatigue limit.

\begin{tabular}{|l|c|c|c|c|c|}
\hline \multirow{2}{*}{$\begin{array}{l}V_{S} \\
{[\mathrm{~m} / \mathrm{s}]}\end{array}$} & \multirow{2}{*}{$\begin{array}{l}\text { Slip } \\
\text { ratio } \\
{[\%]}\end{array}$} & $\begin{array}{l}\text { Pitting } \\
\text { strength } \\
{[\mathrm{MPa}]}\end{array}$ & $\begin{array}{l}\text { Lubrication } \\
\text { failure } \\
\text { limit [MPa] }\end{array}$ & $\begin{array}{l}\text { Pitting } \\
\text { strength } \\
\text { [MPa] }\end{array}$ & $\begin{array}{l}\text { Lubrication } \\
\text { failure } \\
\text { limit [MPa] }\end{array}$ \\
\hline \multirow{4}{*}{1.36} & 40 & 2500 & - & 2400 & - \\
\cline { 2 - 6 } & 80 & 2100 & 2300 & 2100 & - \\
\cline { 2 - 6 } & 120 & - & - & $>1900$ & 2000 \\
\cline { 2 - 6 } & 160 & $>1300$ & 1400 & $>1600$ & 1700 \\
\hline 0.41 & 80 & - & - & 1800 & - \\
\hline
\end{tabular}


ベり率 $80 \%$ の条件では, ヘルツ応力が高い領域でスコー リング，ヘルツ応力が低い領域でピッチングという $2 つ$ の形態の損傷が発生した.

\section{$3 \cdot 2$ すべり率の影響}

Fig. 9 に，ピッチング強度と焼付き限度に及ぼすすべ り率の影響を整理して示す。これより, 油温 $353 \mathrm{~K}, 313 \mathrm{~K}$ の両方で, すべり率の増加とともにピッチング強度, 焼 付き限度とも低下することがわかる．また，ピッチング 強度の線と焼付き限度の線は, すべり率の増加とともに 近接し，すべり率 $80 \%$ と $160 \%$ の間で交差することがわ かる.

\section{$3 \cdot 3$ 油温および周速の影響}

Fig. 10 に，ピッチング強度と焼付き限度に及ぼす油温 と周速の影響を整理して示す。これより，ピッチング強度 は油温とともに若干上昇するが, 焼付き限度は低下する ことがわかる.すなわち, 油温を下げると, 焼付きを抑制 することができる。これは, 潤滑油の粘度・油膜厚さの 増加に起因していると推定される.さらに, Fig. 10 より ピッチング強度は, 周速の増加とともに上昇することが わかる.これらの理由については後で考察する.

\section{4 考察}

\section{$4 \cdot 1$ ピッチング強度の摩擦係数および接触面温度に よる整理}

第 3 章の試験結果を考察するため, 小ローラー軸のト ルクから摩擦係数を, 小ローラー接触面表面に取り付

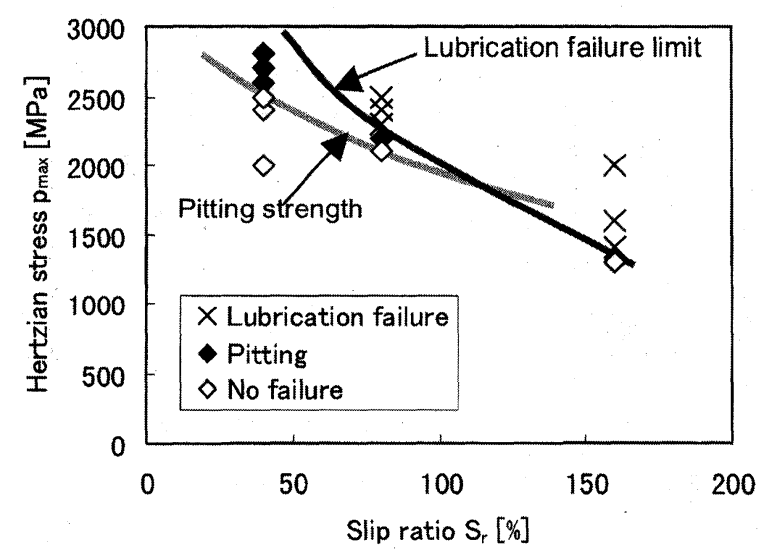

(a) Oil temp. 353K

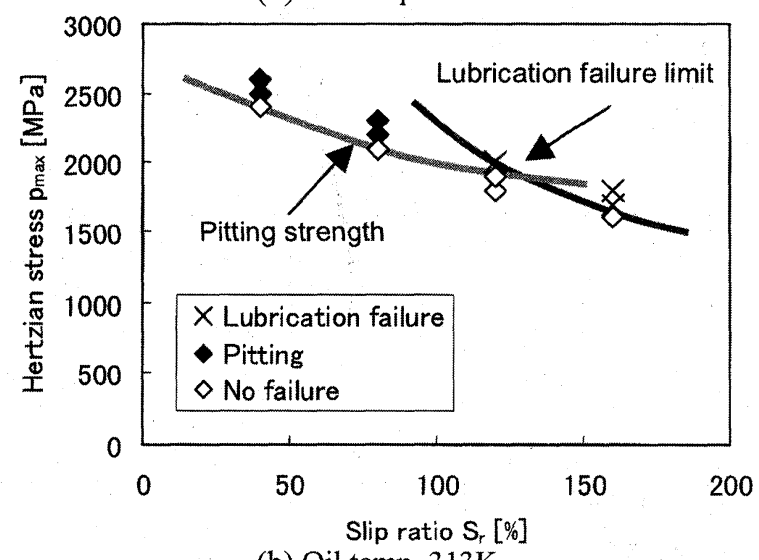

(b) Oil temp. $313 \mathrm{~K}$

Fig. 9. Effect of slip ratio.
けた接触式熱電対 (安立計器製) から接触面温度を測定 した.ここで, 熱電対は小ローラーが大ローラーと接触 した後，3/4 周回った位置に取り付けている。このため， 接触面の真の温度より若干低めの温度を計測しているこ とになる。ただし，接触時と温度測定時の時間差は， 高々, 周速 $1.36 \mathrm{~m} / \mathrm{s}$ で $0.045 \mathrm{sec}$, 周速 $0.41 \mathrm{~m} / \mathrm{s}$ で 0.149 secのレベルである。一方, 摩擦係数 $\mu$ は, 小ローラー 軸のトルク Tから, 次式に示すように, 接線力を押付け 荷重で除すことによって算出している.

$$
\mu=\mathrm{T} /(\mathrm{r} \cdot \mathrm{P})
$$

ここで, $r$ ：小ローラー半径 $(13 \mathrm{~mm}), \mathrm{P}$ ：押付け荷重 試験条件は, Table IIIに示した周速, 油温, すべり率の 組合せで, ピッチング強度と同じレベルのヘルッ応力と した。摩擦係数，接触面温度ともに，測定用に用意した 試験片を用い，試験開始後 $500 \mathrm{sec}$ から 2000sec までを 周波数 $4 \mathrm{~Hz}$ でサンプリングしたデータを平均している. なお，予め別条件で長時間（繰返し数にして $5 \times 10^{5}$ ), 同様の測定を行い，上記短時間の測定でほほ同じ測定結 果が得られることを確認している.

Table IVに, 測定の結果得られた摩擦係数と接触面温 度の一覧を示す. Table IVのデータを用いて, ピッチン グ強度と摩擦係数との関係を整理した。 Fig. 11 にその 結果を示す。これより, ピッチング強度は, 周速, 油温, すべり率の組合せによらず, 摩擦係数の増加とともに線 形的に低下する 1 本の線で整理できることがわかる.

Fig. 11 中のプロット点では, 摩擦係数とともに, 接 触面温度が Table IVに示すようにそれぞれ異なる。にも かかわらず，上記のように摩擦係数のみで整理できるこ とは, 接触面温度の影響が比較的小さいことを意味して いる. Fig. 12 に, 小ローラー接触面から切り出した試 料を焼もどしした時の表面硬さの変化を示す. 図中には, Table IVに示した接触面温度の範囲も示している.これ より, 試験での接触面温度は, 小ローラー表面層が焼も どし軟化する領域よりかなり低い領域にあることがわか る. 前述したように, 接触面温度の測定值は, 接触時と 測定時の時間差から，真の温度より低めになるものの， 試験後の硬さの低下も見られなかったことから, 接触面 の温度上昇による軟化は起こっていないと推定される.

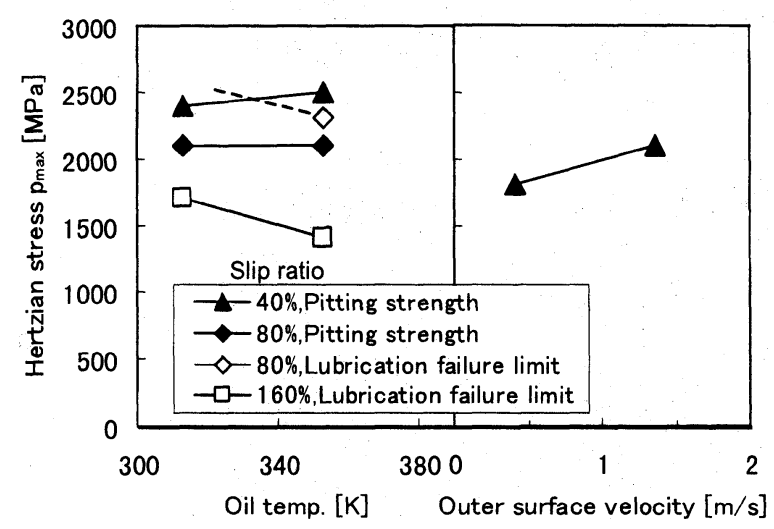

Fig. 10. Effect of oil temperature and outer surface velocity. 
Table IV . List of the friction coefficient and contact surface temperature.

\begin{tabular}{|c|c|c|c||c|c|}
\hline $\begin{array}{c}\text { Outer } \\
\text { surface } \\
\text { velocity } \\
{[\mathrm{m} / \mathrm{s}]}\end{array}$ & $\begin{array}{c}\text { Oil } \\
\text { temp. } \\
{[\mathrm{K}]}\end{array}$ & $\begin{array}{c}\text { Slip } \\
\text { ratio } \\
\mathrm{S}_{[}[\%]\end{array}$ & $\begin{array}{c}\text { Hertzian } \\
\text { stress } \\
{[\mathrm{MPa}]}\end{array}$ & $\begin{array}{c}\text { Friction } \\
\text { coefficient } \\
\mu\end{array}$ & $\begin{array}{c}\text { Contact } \\
\text { surface } \\
\text { temperature } \\
{[\mathrm{K}]}\end{array}$ \\
\hline \hline \multirow{4}{*}{1.36} & \multirow{3}{*}{353} & 40 & 2500 & 0.029 & 392 \\
\cline { 3 - 6 } & & 80 & 2100 & 0.045 & 404 \\
\cline { 2 - 6 } & & 160 & 1300 & 0.075 & 383 \\
\cline { 3 - 6 } & \multirow{3}{*}{313} & 40 & 2400 & 0.029 & 362 \\
\cline { 3 - 6 } & & 80 & 2100 & 0.050 & 377 \\
\cline { 3 - 6 } & & 120 & 1900 & 0.060 & 374 \\
\hline \multirow{2}{*}{0.41} & 313 & 80 & 1600 & 0.077 & 370 \\
\hline
\end{tabular}

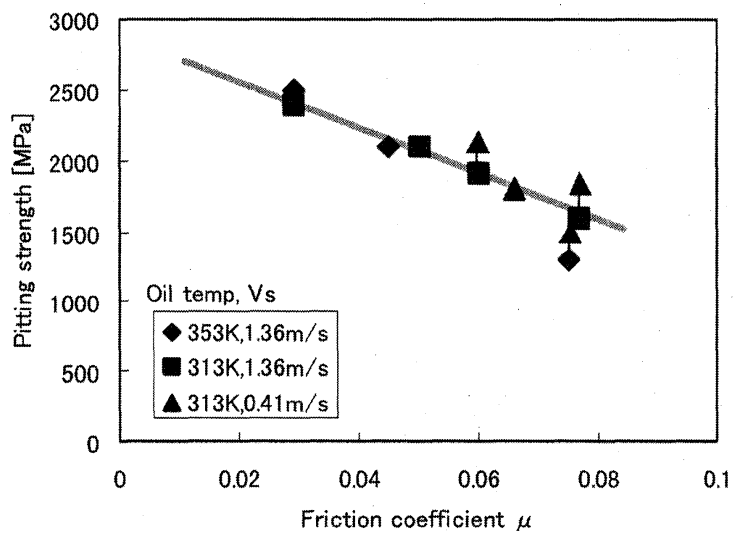

Fig. 11. Relationship between pitting strength and friction coefficient.

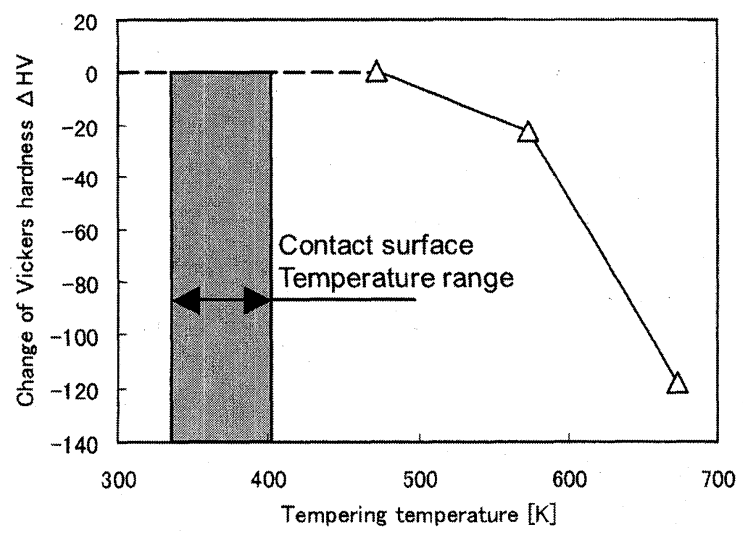

Fig. 12. Change of Vickers hardness due to tempering temperature.

このため，接触面温度はピッチング強度にほとんど影響 しなかったと考えられる。

\section{$4 \cdot 2$ 摩擦係数の支配因子}

$4 \cdot 1$ 節で摩擦係数がピッチング強度を決定する重要な パラメータであることが判明したが，ここでは摩擦係数 がどのような因子に支配されているかを明らかにするた め, Table IVよりさらに網羅的な条件で摩擦係数と接触 面温度を測定した。

Fig. 13 に, 摩擦係数と接触面温度との関係を示す。こ れより，摩擦係数は接触面温度の上昇にともない若干低

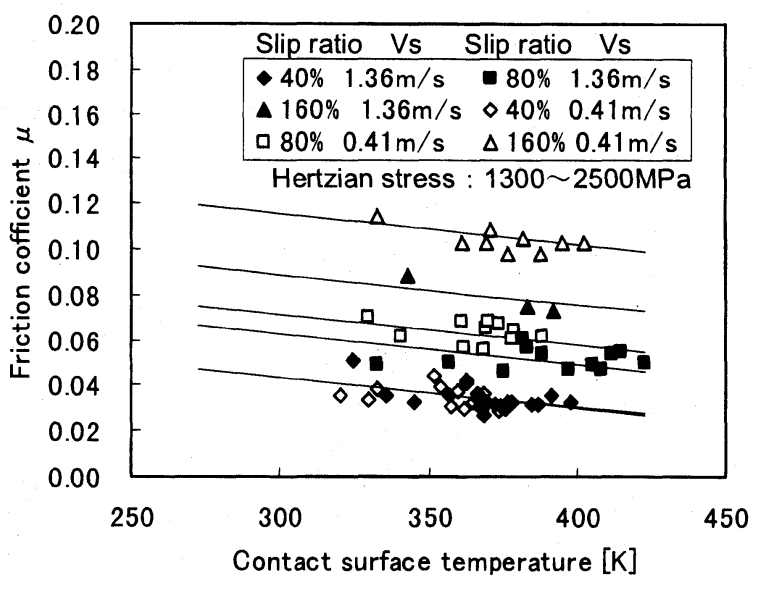

Fig. 13. Relationship between friction coefficient and contact surface temperature.

下する．ただし，摩擦係数のレベルはすべり率と周速に よって異なる。図中の同じ種類のプロット点群で接触面 温度が異なるのは，面圧が変化しているためである。す なわち，面圧は，摩擦係数に直接影響するのではなく， 接触面温度を介して間接的に影響している. $3 \cdot 2$ 節で油 温の上昇によりピッチング強度が若干上昇したのは，油 温上昇により接触面温度が上昇し，摩擦係数が低下した ためと推定される.

Fig. 13 中の接触面温度 $373 \mathrm{~K}$ での摩擦係数に着目し て，すべり率との関係を整理した結果を，Fig. 14 に示 す。これより，摩擦係数は，接触面温度一定としても， すべり率の増加とともに上昇することがわかる，この傾 向は過去の文献と異なる。一般に, 摩擦係数は, すべり 率の増加とともに上昇するが，あるすべり率を超えると 飽和または漸减する傾向を示す３，4)，8これに対し，本研

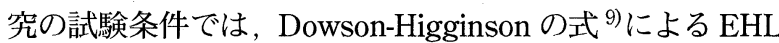
最小油膜厚さが $0.08 \sim 0.20 \mu \mathrm{m}$ であり，表面粗さ $\mathrm{R}_{\max }$ を この油膜厚さで除した $\mathrm{D}$ 值は，5 以上となるため，十分 な油膜厚さが確保できていないと推定される。また, 試験 中に表面粗さは若干減少するが，それでも上記油膜厚さ より十分大きく $\mathrm{D}$ 值にして 3 以上であることを確認し ている.したがって，微視的には小ローラーと大ローラー

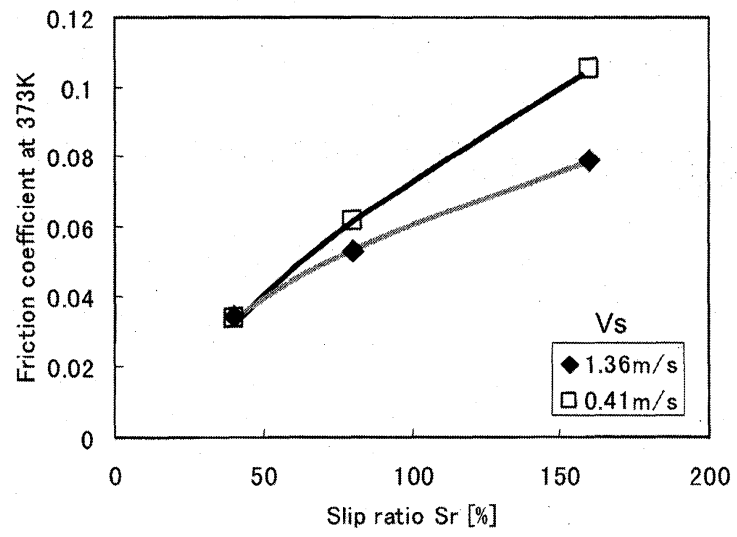

Fig. 14. Relationship between friction coefficient at $373 \mathrm{~K}$ and slip ratio. 
の間で金属接触が粗さの突起単位で生じることから，す べり率の増加とともに摩擦係数が上昇したと考元られる。

さらに, Fig. 14 より, 摩擦係数は, 同じすべり率で も周速の增加ととともに減少し，只の減少幅はすべり率 の增加とともに增大していることがわかる、3・3 節で周 速の増加によりピッチング強度が上昇したのは，周速増 加により摩擦你数が低下したためと推定される。

\section{$4 \cdot 3$ 表面下のき裂の進展形態}

$3 \cdot 1$ 節でピッチング損傷として, 矢じり型き裂起点と スクエア型の 2 形態が観察されることを述べた。兄こで, この損傷の断面にて表面下のき裂の進展形態を観察した。

Fig. 15 に，ピッチングを生じた試験片の軸方向に垂直 な断面の光学顕微鏡写真を示す。図中 (a) は矢じり型き 裂起点のピッチングの断面，(b) は (a) と同じ試験片に観 察された浅いき裂の搪大写真，(c) はスクエア型ピッチン グの断面，(d) は (c) と同じ試験片に観察されたさ裂の拡 大写真である。図中(a)より, 矢じり型き裂起点のピッチ ングでは，表面から斜めにき裂が進展し，市る深さで分 岐している。この進展形態より, き裂面内の油圧作用に よってMode I主体でき裂が進展したと推定される、10) 図中 (b) より，はく離に至っていない浅いき裂でも表面 に接していることがわかる。摩擦係数は接触面のせん断 応力㧍よび接触面通過前後の円周方向応力の変動量を増 大させる5゙た，表面が起点であると孝えれば，Fig. 11 に示したようにピッチング強度が摩擦係数に大きく影響 さ机ていることが理解でさる。Fig. 15 の (c) より，スク エア型のピッチングでは，き裂はほぼ円周方向に平行に 進展して打り，深さ方向には進展していないことがわか る。また図中(d)より，はく離に至っていない内部き裂が， 深さ $0.2 \sim 0.3 \mathrm{~mm}$ に生じていることがわかる。この深さ は, ヘルツ理論による接触半幅の $1 / 2$ に対応しているこ とから, 内部のせん断応力の絽返しに起因して, き裂が 発生し, Mode II主体で進展し，はく離に至ったと考元ら れる。通常，この上うな内部起点のスクエア型ピッチング は，すべりの無い条件で観察される、4しかしながら，本
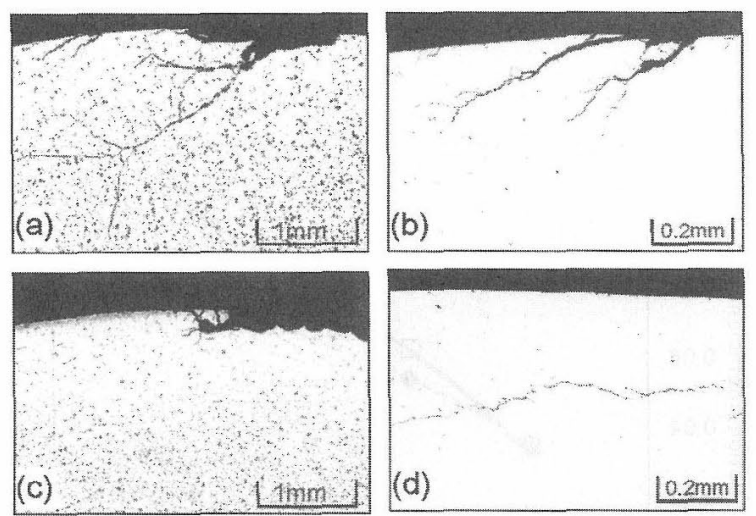

4 Load moving direction,

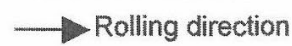

Fig. 15. Cross section view of pitting and cracks.
研究では，すべり率 $40 \%$ 扎よび $80 \%$ で散見された。これ は，内部起点の場合，介在物等のばらつき多く含光因 子が支配因子となり，ピッチング強度自休もばらつきが 大きくなったためと考光られる。

\section{5 結言}

浸炭材を対象として，ピッチング強度に及ぼすすべり 率，周速，および潤滑油温度等のすべり条件の影響老明 らかにすることを目的とし，油潤滑による種々のすべり 条件下で転がり接触疲労試験是行った。乥の結果，以下 のことがわかった。

（1） 発生したピッチングの性状は矢じり型き裂を起点 とした形態が主体であったが，一部に，き裂が表面下で 円周方向に平行に進展してはく離した，スクエア型の形 態も観察された。

(2) 油温の上昇，すべり率の増加にともない，ピッチ ングに代わって，煍付き，またはスコーリングが発生し やすくなる。

(3) すべり率の増加とともにピッチングに関する疲労 限度（ピッチング強度），焼付き限度とも低下する。

(4) ピッチング強度は油温とともに若干上昇するが， 焼付き限度は低下する。

（5）ピッチング強度は，周速の增加とともに上吕する。

(6) 上記 (3) から (5) の結果は, 摩擦係数によって一 元的に整理できる。すなわち, ピッチング強度は, 周速, 油温，すべり率によらず，摩擦你数の增加とともに線形 的に低下寸る。

(7) 上記 (6) の結果は, 接触面温度の影響が, 摩擦 你数と比較して相対的に小さいことを意味している。た だし，接触面温度は，摩擦係数に影響することで, 問接 的にピッチング強度に影響している。

\section{参考 文 献}

1）成瀨長太郎, 機械の研究，45-10，39（1993）。

2) 石橋 彰, 吉野英弘, 中島嚴, 日本機械学会論文集 (第 3 部)，42，2207 (1976)。

3) 赤岡 純, 似内昭夫, 潤滑, 27,268（1982）。

4) 鈴木智博, 小川一義, 堀田昇次, 横川光義, 日本機械学 会論文集, C-65，3751 (1999)。

5) 森本精洋, 松本镇一, 武田晴之, 材料, 50, 1323 (2001).

6 ）木南俊哉, 中村貞行, CAMP-ISIJ, 10, 472 (1997).

7 ）黑川八寿男, 鎌田芳彦, 西田和彦, 村井啺宏, 住友金属, 48, 204 (1996).

8) 三由 久, 高田 潤，機械技術研究所所報，26-5, 17 (1972).

9）山本雄二，兼田楨宏，“トライボロジー”, p.119 (1998) 理工学社。

10）村上敬宜, 栄中, 市丸和德, 森田健敬, 日本機械学 会論文集，C-62，683（1996）。 